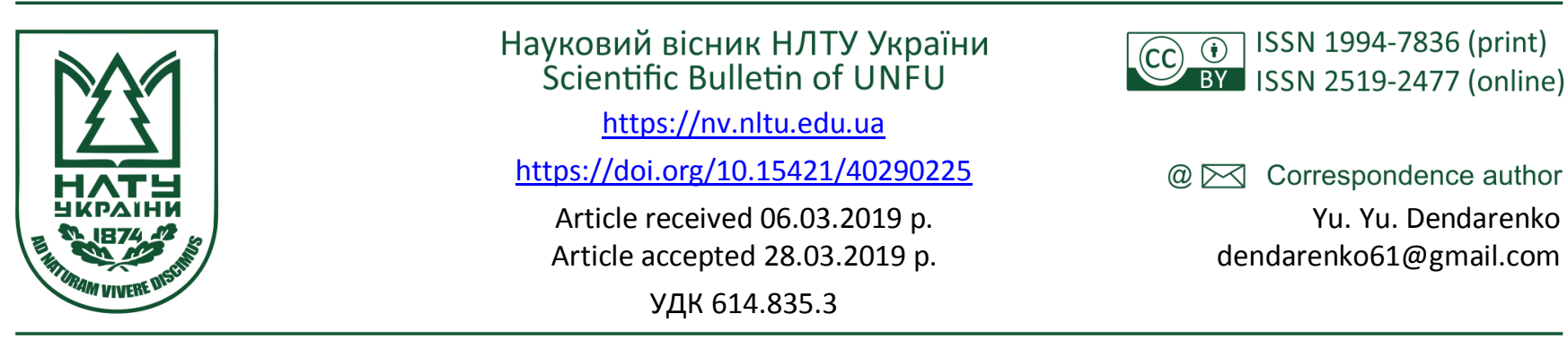

Yu. Yu. Dendarenko1, V. I. Dyven', Ye. O. Tyshchenko², O. D. Blashchuk1

${ }^{1}$ Cherkasy Institute of Fire Safety named after Chornobyl Heroes of National University of Civil Defense of Ukraine, Cherkasy, Ukraine ${ }^{2}$ Educational and Methodical Center for Civil Protection and Life Safety, Cherkassy, Ukraine

\title{
PECULIARITIES OF DEVELOPMENT AND EXTINGUISHING FIRES AT THE OBJECTS WHERE LIQUIFIED PETROLEUM GAS IS STORED
}

\begin{abstract}
The possibility of using sprayed water jets is established, primarily radial air jets, in vertical and horizontal planes in order to reduce the temperature of the burning Liquefied Petroleum Gas, starting from the cut-off of its expiration into free space. Various technical means of supplying water in a spray and spray nozzles for their creation, which are used in solving the problem of reducing the temperature of the burning Liquefied Petroleum Gas are viewed. It has been established that the active phase of the sprayed water jet is most effective $(0,5-0,75$ of the lengths), which, acting under the cut of the flame is crushed to a finely dispersed phase under the influence of a high-speed gas jet. As can be seen from the above, the heating rate of the finely dispersed water phase is increased up to the gaseous state, which leads to a decrease of the temperature of the flame in its middle combustion zone. Consequently, in the flame temperature will be much lower than the temperature of the flame cone, and, as a result, close to the extinction temperature. The authors recommend the use of modern jet-forming devices to realize this goal-nozzles NRT-5, NRT-10, NRT-20, NRS, as well as hand nozzles of the kind RSK-50, RS-A, RS-B, PROTEK. In order to cool, for example, one horizontal ground steel tank on both sides, it is necessary to use at least two hydraulic guns, which will act as maneuvering. In this case, the flow of water from the hydraulic gun with a diameter of the nozzle $25 \mathrm{~mm}$ will be from 16 to 18 liters per second. Therefore, the task is to find, calculate and experimentally prove the efficiency of the thermal screen, which is created in the form of a moving water surface that can effectively protect a particular physical object from the thermal impact of the heat zone. In order to reduce the flow of water to cool the tanks, the authors suggest using the NRS to create radial (flat) water jets. Application of such a nozzle allows to increase the area of simultaneous cooling of the maximum surface area per unit time due to the expansion of the angle of the spray jet spark. The water consumption does not exceed 13 liters per second.
\end{abstract}

Keywords: heat current; water spray; nozzle; Liquefied Petroleum Gas.

Introduction. Peculiar features of the development of fires at the objects where Liquefied Petroleum Gas (LPG) is processed and stored are determined by the properties of this gas. During depressurization of the facilities and free emission of LPG to the atmosphere, due to the high velocity of evaporation vapor clouds of large size may be formed, which depend on the amount of gas, that immediately blasted, or the speed of the emission, as well as climatic conditions (wind speed, air temperature, etc.).

The most probable cause of an emergency leakage of the product is the loss of tightness of the equipment due to a violation of the technological process and malfunction of emergency systems and devices. As a rule, an outbreak occurs from a third-party source, because the maximum temperature of the product does not exceed the temperature of self-ignition.

Materials and methods of research. Fires at the objects where LPG is processed and stored are characterized by the possibility of manifestation in various combinations of such dangerous phenomena:

- thermal influence of the "inflammation" (explosive initiation);

- the influence of the compressed air wave (explosive blast);

- thermal influence of the jet flame of burning gas;

- thermal influence of the flame of the pool fire;

- thermal influence of the fire ball.

Since the density of the vapor of most LPG exceeds the air density, vapor clouds can drift in the surface layer of the atmosphere at considerable distances. During the burning of such clouds, their rapid combustion may occur without an explosion in the form of a flash or combustion with an explosion with the formation of a compression wave.

Combustion with an explosion with the formation of a compression wave may occur, when vapor clouds cover cluttered areas of the territory (half-closed volumes, technological equipment with high density of placement, forest arrays), as well as when the long pipes, cavities and so on get

\section{Інформація про авторів:}

Дендаренко Юрій Юрійович, канд. техн. наук, доцент, кафедра пожежної тактики та аварійно-рятувальних робіт. Email: dendarenko61@gmail.com

Дивень Валентин Іванович, канд. істор. наук, доцент, кафедра пожежно-профілактичної роботи. Email: valentin_diven@ukr.net

Тищенко Евгений Александрович, канд. техн. наук, доцент, заступник начальника навчально-методичного центру. Email: dendarenko61@gmail.com

Блащук Олександр Дмитрович, завідувач відділення заочного навчання. Email: dendarenko61@gmail.com

Цитування за ДСТУ: Дендаренко Ю. Ю., Дивень В. І., Тищенко Є. О., Блащук О. Д. Peculiarities of development and extinguishing fires at the objects where liquified petroleum gas is stored. Науковий вісник НлТУ України. 2019, т. 29, № 2. С. 124-126.

Citation APA: Dendarenko, Yu. Yu., Dyven, V. I., Tyshchenko, Ye. O., \& Blashchuk, O. D. (2019). Peculiarities of development and extinguishing fires at the objects where liquified petroleum gas is stored. Scientific Bulletin of UNFU, 29(2), 124-126. https://doi.org/10.15421/40290225 
into the cloud.

During depressurization of the facilities, in which liquefied gases are under pressure, steam-air jets are formed, the ignition of which leads to the formation of radial jet flames, as well as jet flames, close to the symmetric axis. The influence of such flames, that often have a large length, on the facilities leads to its damage and the involvement of more and more gas to the combustion.

The thermal influence of jet flame or pool fire on the liquefied petroleum storage tanks may destroy them and form fire balls with a large radius of mortal damage to people by thermal radiation.

When storing liquefied gases in isothermal land repositories, there is a great danger of the possible destruction of such repositories. The hydrodynamic wave formed in such cases can destroy the bund wall or overflow through it with the formation of straits of large areas. When liquefied gas is evaporating from such straits, steam-air clouds of large size are formed. The burning of such straits can lead to fires in neighboring objects.

One of the peculiar features of the fires at the objects where LPG are stored and processed is the possibility of chain (cascade) fire development.

According to the authors, in order to prevent the development of a fire and its elimination, it is necessary to proceed from the following:

- if it is impossible to prevent the flow of the LPG into open space it is necessary to ensure its burnout under control;

- all actions on the localization of the fire should be aimed at preventing its development and the effects of hazardous fire factors on the personnel;

Table. Technical Characteristics of Modern Means to Create Spray Water Jets

\begin{tabular}{|c|c|c|c|c|}
\hline \multirow[t]{2}{*}{ Types of Fire } & \multirow{2}{*}{$\begin{array}{l}\text { Fire Extinguishing } \\
\text { Agents }\end{array}$} & \multirow[t]{2}{*}{ Method of Application } & \multicolumn{2}{|c|}{$\begin{array}{l}\text { Fire-Fighting Equipment for Spray Water Jets } \\
\text { Application }\end{array}$} \\
\hline & & & Hand-Held Branch & Adjustable Nozzle \\
\hline $\begin{array}{l}\text { Flare burning } \\
\text { symmetrical along } \\
\text { the axes jets of LPG }\end{array}$ & Spray water jets & $\begin{array}{c}\text { Irrigation of the flame flare with the } \\
\text { active (effective) part of the jet (0,5- } \\
0,75 \text { of the length) (Ivannikov, \& Kli- } \\
\text { us, 1987) }\end{array}$ & $\begin{array}{l}\text { RSK-50 } \\
\text { PROTEK } \\
\text { RS-A } \\
\text { RS-B }\end{array}$ & $\begin{array}{c}\text { NRT-5 } \\
\text { NRT-10 } \\
\text { NRT-20 } \\
\text { Nozzles for radial water } \\
\text { jets (NRS) } \\
\text { (Dendarenko, 2004) }\end{array}$ \\
\hline $\begin{array}{l}\text { Flare burning of fan- } \\
\text { type jets of LPG }\end{array}$ & Spray water jets & $\begin{array}{l}\text { Irrigation of the flame flare with the } \\
\text { active (effective) part of the jet }(0,5- \\
0,75 \text { of the length) with the purpose of } \\
\text { localization of combustion }\end{array}$ & $\begin{array}{c}\text { RSK-50 } \\
\text { PROTEK } \\
\text { RS-A } \\
\text { RS-B } \\
\end{array}$ & $\begin{array}{c}\text { NRT-5 } \\
\text { NRT-10 } \\
\text { NRT-20 } \\
\text { NRS } \\
\end{array}$ \\
\hline \multirow[t]{2}{*}{ The strait burning } & Spray water jets & $\begin{array}{l}\text { The flares of the sprayed water jets } \\
\text { must overlap the entire combustion } \\
\text { surface }\end{array}$ & & \multirow{2}{*}{$\begin{array}{l}\text { NRT-5 } \\
\text { NRT-10 } \\
\text { NRT-20 } \\
\text { NRS }\end{array}$} \\
\hline & $\begin{array}{c}\text { Air-mechanical foam of } \\
\text { average multiplicity }\end{array}$ & $\begin{array}{c}\text { Isolation of the entire surface of the } \\
\text { strait }\end{array}$ & $\begin{array}{l}\text { GPS-600 } \\
\text { GPS-2000 }\end{array}$ & \\
\hline
\end{tabular}

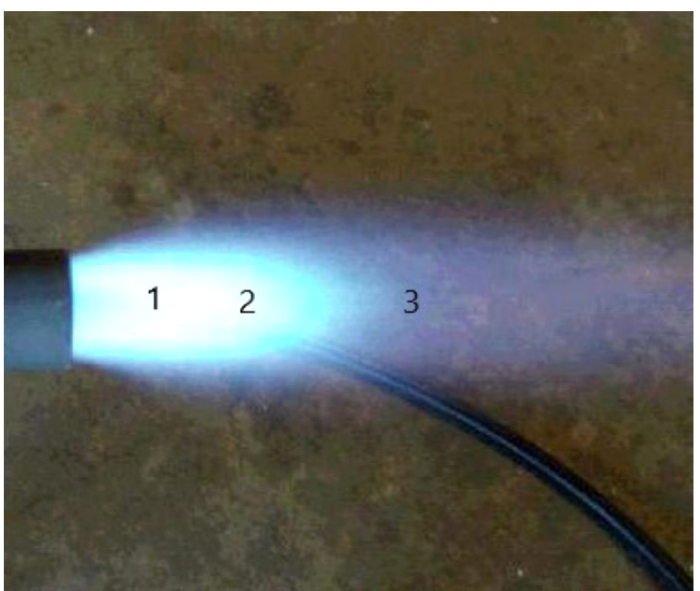

Fig. 1. The structure of the formation of high-speed gas flame when it enters the airspace through a free hole
- fireground commander has to evaluate timely the possibility of manifestation of hazardous factors that could endanger the health and life of the personnel and ensure timely evacuation into a safe area.

For this purpose methods of quantitative assessment of the parameters of the acute factors of accidents with fires and explosions should be used for the development of fire extinguishing plans at the objects where the LPG are stored.

When considering the physicochemical properties and indicators of explosive hazardous substances, it should be taken into account that in practice, as a rule, dealing with a two-phase liquid-gas system (steam) takes place.

Primary goal of the fireground commander and units of the rescue service is the localization of combustion of LPG and creation of safe conditions for the burnout of the product.

Technical characteristics of modern fire-fighting means to create spray water jets, which can be used to reduce the intensity of the heat flow by irrigation of the flame flare were analyzed (Table).

Results. Through computer simulation and simulation in laboratory conditions authors came to the conclusion, that the most effective actions of the units of the rescue forces during the accidental occurrence of jet spray combustion LPG is the use of spray jets of fan type. Usage of the active phase of such a jet (0,5-0,75 of its length), when applied directly under the cutting zone of the core of the flame 1 , that is a high-speed stream (Fig. 1), it is possible to achieve the maximum fractionation of the water jet into the fine-dispersed phase and so to increase the speed of its heating up to the limit of the gaseous state, which will reduce the temperature of the flame in its middle zone of renewal 2 at the expense of intensive heat removal from the combustion zone to the heating and evaporation of water.

Thus, the temperature of the flame at the flare area 3 will be much lower than the core temperature and, as a result, closer to the extinction temperature.

In order to cool, for example, one horizontal ground steel tank on both sides, it is necessary to use at least two hydraulic guns, which will act as maneuvering. In this case, the flow of water from the hydraulic gun with a diameter of the nozzle $25 \mathrm{~mm}$ will be from 16 to 18 liters per second (Ivannikov \& Klius, 1987). Therefore, the task is to find, calculate and experimentally prove the efficiency of the thermal screen, which is created in the form of a moving water surface that can effectively protect a particular physical object from the thermal impact of the heat zone.

In order to reduce the flow of water to cool the tanks, the authors suggest using the NRS to create radial (flat) water jets (Fig. 2) (Dendarenko, 2004; Sherenkov \& Denda- 
renko, 2002). Application of such a nozzle allows to increase the area of simultaneous cooling of the maximum surface area per unit time due to the expansion of the angle of the spray jet spark. The water consumption does not exceed 13 liters per second (Dendarenko, 2004).

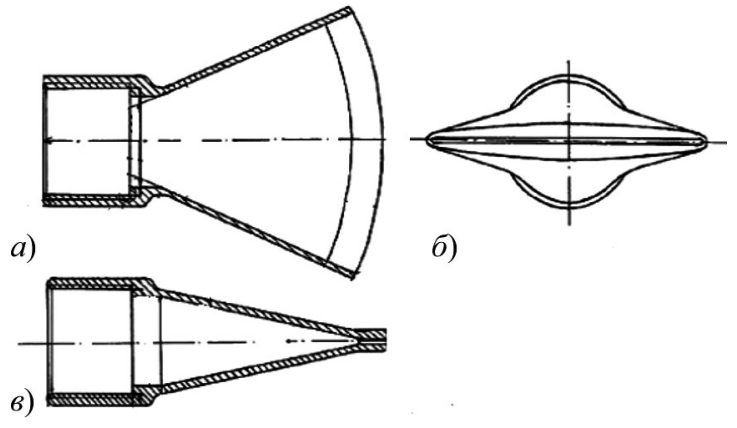

Fig. 2. General View of the NRS

At Fig. 3; 4 possible schemes for the use of the NRS for the cooling of emergency horizontal and globular ground metal tanks with liquefied gas are shown.

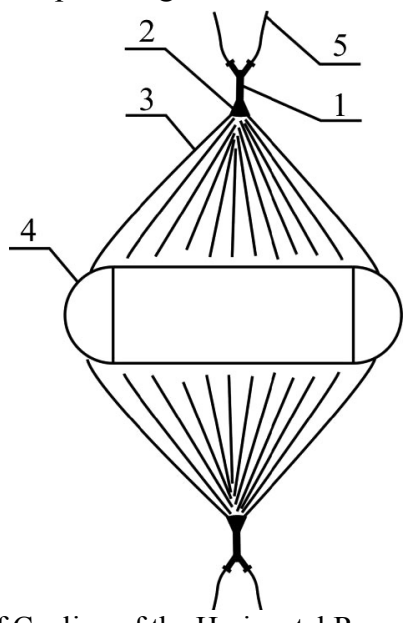

Fig. 3. Scheme of Cooling of the Horizontal Reservoirs with Liquefied Gas via NRS During a Fire: 1) hydraulic gun PLS-20P;

2) NRS; 3) radial water jet; 4) horizontal ground steel reservoir;

5) pressure fire hose lines

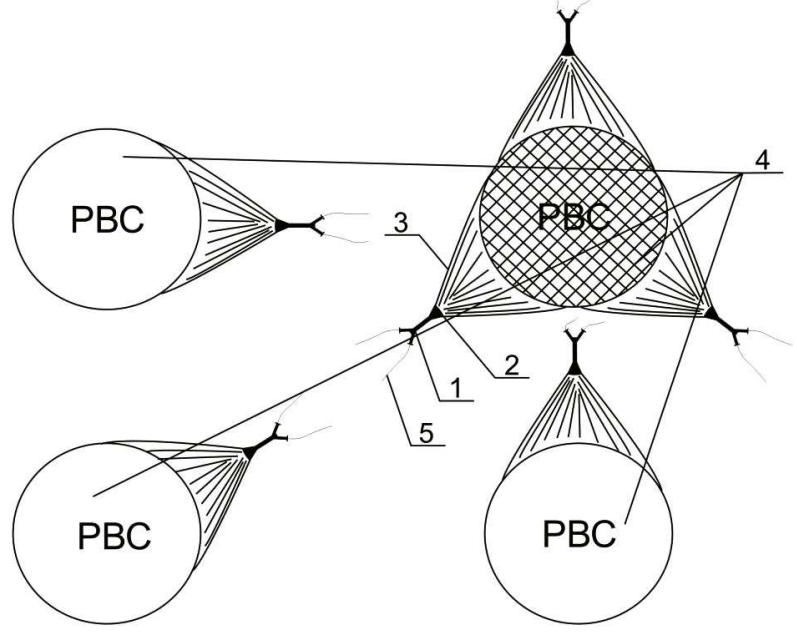

Fig. 4. Scheme of Cooling of the Globular Reservoirs with Liquefied Gas via NRS During a Fire: 1) hydraulic gun PLS-20P; 2) NRS; 3) radial water jet; 4) globular steel reservoir; 5) pressure fire hose lines

\section{Conclusions:}

1. One can implement an active impact on reducing flame temperature of the burning LPG with the help of spray fantype water jet, using the flame structure of the burning LPG by inserting a jet under the cutting zone of its core.

2. A new way of cooling the horizontal and globular liquefied gas tanks is proposed, which will allow to maintain bearing and fencing properties of their structural elements in the conditions of the elimination of fires and emergencies with a significant reduction in water consumption and the required number of personnel of the operational and rescue service units.

\section{Перелік використаних джерел}

Dendarenko, Yu. Yu. (2004). Radialni vodiani strumeni-ekrany dlia protypozhezhnoho zakhystu. Candidate Dissertation for Technical Sciences (05.23.16 - Hydraulics and engineering hydrology). Kharkiv: Kharkivskyi derzh. tekhn. un-t bud. ta arkhit., 121 p. [In Ukrainian].

Ivannikov, V. P., \& Klius, P. P. (1987). Spravochnik rukovoditelia tusheniia pozhara. Moscow: Stroiizdat, 288 p. [In Russian].

Sherenkov, I. A., \& Dendarenko, Iu. Iu. (2002). Veernye svobodnye vodianye strui dlia teplozashhity pri pozharakh. Naukovyi zbirnyk budivnytstva, 18, 293-297. [In Ukrainian].

Ю. Ю. Дендаренко ${ }^{1}$, В. І. Дивень ${ }^{1}$, Є. О. Тищенко ${ }^{2}$, О. Д. Блащук

${ }^{l}$ Черкаський інститут пожежної безпеки ім. Героїв Чорнобиля Національного університету ичивільного захисту Украӥни, м. Черкаси, Україна

${ }^{2}$ Навчально-методичний центр цииільного захисту та безпеки життєдіяльності, м. Черкаси, Україна

\section{ОСОБЛИВОСТІ РОЗВИТКУ ТА ГАСІННЯ ПОЖЕЖ НА ОБ'ЄКТАХ ЗБЕРІГАННЯ} ЗРІДЖЕНИХ ВУГЛЕВОДНЕВИХ ГАЗІВ

Встановлено можливість застосування розпилених водяних струменів, переважно водяних струменів віялового типу, у вертикальній та горизонтальній площинах для пониження температури полум'я палаючих зріджених вуглеводневих газів, починаючи зі зрізу його надходження у вільний простір. Розглянуто різні технічні засоби подавання води у розпиленому вигляді та насадки-розпилювачі для їх створення, які застосовують у вирішенні проблеми зниження температури пожежі зріджених вуглеводневих газів. З'ясовано, що найефективнішою $\epsilon$ активна фаза розпиленого водяного струменя $(0,5-$ 0,75 довжини), яка, надходячи під зріз ядра полум'я, під впливом високошвидкісного газового струменя подрібнюється на дрібнодисперсну фазу. Таким способом збільшується швидкість нагрівання дрібнодисперсної фази води аж до межі газоподібного стану, що призведе до зниження температури полум'я у його середній зоні поновлення завдяки інтенсивному відбору тепла із зони горіння. Отже, у факельній зоні температура полум'я буде значно нижчою за температуру ядра та, як наслідок, наближеною до температури стухання. Для реалізації цієї мети рекомендовано застосування сучасних струменеутворювальних пристроїв - насадки НРТ-5, НРТ-10, НРТ-20, НРС, а також ручні пожежні стволи типу РСК-50, РС-А, РC-Б, PROTEK.

Ключові слова: тепловий потік; розпилений водяний струмінь; насадок; зріджений вуглеводневий газ. 